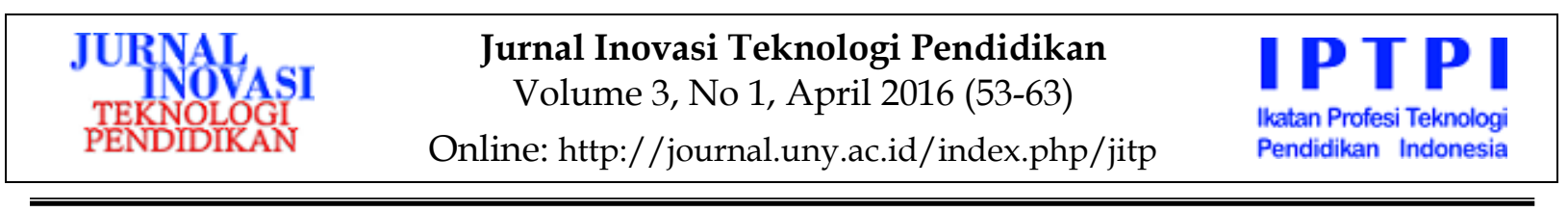

\title{
PENGEMBANGAN MULTIMEDIA PEMBELAJARAN RIAS WAJAH DALAM MENINGKATKAN PENGETAHUAN SISWA SMK KECANTIKAN KULIT KELAS X
}

\author{
Siska Miga Dewi, Mukminan \\ Universitas Negeri Padang, Universitas Negeri Yogyakarta \\ siskamigadewi@uny.ac.id,mukminan@uny.ac.id
}

\begin{abstract}
Abstrak
Penelitian ini bertujuan untuk: (1) menghasilkan multimedia pembelajaran rias wajah dalam meningkatkan pengetahuan siswa SMK kecantikan kulit kelas $X$ yang layak digunakan dalam proses pembelajaran rias wajah, dan (2) mengetahui keefektifan produk multimedia pembelajaran rias wajah dalam meningkatkan pengetahuan siswa. Model penelitian dan pengembangan ini dilakukan melalui tiga tahap, yaitu perencanaan, desain dan pengembangan. Proses validasi terhadap produk dilakukan dengan tahap uji alpha, uji beta dan uji coba produk. Hasil penelitian sebagai berikut. (a) Multimedia dikembangkan dinilai layak digunakan dalam pembelajaran ditinjau dari media, materi, dan penilaian siswa. Kelayakan tersebut dapat dilihat dari skor penilaian ahli media 4,2 kategori baik, skor ahli materi 4,9 kategori sangat baik, dan skor penilaian siswa 4,4 kategori sangat baik. (b) Multimedia pembelajaran rias wajah yang menggunakan Macromedia Flash dinilai efektif karena dapat meningkatkan pengetahuan siswa. Hal ini dibuktikan dengan hasil nilai pretest dengan rata-rata nilai 61,0 dan nilai post-test dengan rata-rata nilai 83,9 . Persentase ketuntasan belajar siswa $100 \%$.
\end{abstract}

Kata kunci: multimedia, rias wajah, kecantikan

\section{DEVELOPING MULTIMEDIA IN MAKE-UP LEARNING FOR INCREASING THE KNOWLEDGE OF GRADE $X$ STUDENTSOF VOCATIONAL SCHOOL OF SKIN BEAUTY}

\author{
Siska Miga Dewi, Mukminan \\ Universitas Negeri Padang, Universitas Negeri Yogyakarta \\ siskamigadewi@uny.ac.id,mukminan@uny.ac.id
}

\begin{abstract}
This research aims to: (1) product multimedia on make-up learning in increasing students' knowledge vocational of skin beauty, and (2) know the effectivness of multimedia product on make-up learning in increasing students' knowledge on learning process. It applied the research and development with 3 stages, i.e.: planning, design, and development. The process of validation of this product was carried out through 3 stages, i.e.: alpha testing, beta testing and product testing. The results of the study are as follows. (a) Multimedia learning developed is judged worthy tobe used as a learning in terms of media, materials, and students' assessment. Feasibility can be seen from the expert assessment score of 4.2 in media with good category, a score of 4.9 with category expert material very good, and students' assessment score of 4.4 with very good category. (b) Multimedia on makeup learning using Macromedia Flash is considered effective because it can increase students'

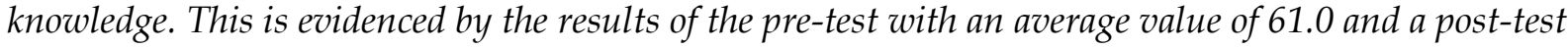
value with an average value of 83.9. The percentage of students' learning mastery is $100 \%$.
\end{abstract}

Keywords: multimedia, make-up, beauty 


\section{Pendahuluan}

Pendidikan adalah usaha sadar dan terencana mewujudkan suasana belajar dan proses pembelajaran agar siswa secara aktif mengembangkan potensi dirinya sendiri. Pengertian ini merupakan perwujudan perubahan mendasar dari pengajaran menjadi pembelajaran (Pasal 3 UU-No-20Tahun-2003-Sisdiknas, 2003). Pengajaran istilah yang mewakili peranan dominan guru sebagai pengajar, sedangkan pembelajaran menunjuk peranan siswa aktif sekaligus mengoreksi peranan dominan guru (Dananjaya, 2013, p. 25). Istilah pengajaran dan pembelajaran bukan hanya istilah teknis, tetapi istilah yang memangku perubahan paradigma.

Perubahan paradigma yang terjadi diadopsi ke dalam sistem pendidikan nasional yang secara teoristis disebut student centered learning (SCL) atau pembelajaran berpusat pada siswa yang merupakan pendekatan pembelajaran pada kurikulum 2013 yang dicanangkan dan dilaksanakan dua tahun belakangan ini. Hal ini tertuang jelas dalam Permendikbud No. 81A tahun 2013 tentang Implementasi Kurikulum 2013.

Menurut Nanney (2004, p. 11), yang dimaksud dengan SCL adalah "a broad teaching approach that encompasses replacing lectures with active learning, integrating selfpaced learning programs and/or cooperative group situations, ultimately holding the student responsible for his own advances in education. Dapat dijelaskan bahwa SCL adalah sebuah pendekatan yang mencoba mengubah pembelajaran menjadi lebih aktif dan terpadu yang akhirnya membuat siswa bertanggungjawab terhadap perkembangannya dalam pendidikan.

Dengan penerapan SCL diharapkan dapat memberi ruang bagi siswa untuk belajar menurut ketertarikannya, kemampuan pribadinya, dan gaya belajarnya yang mana siswa secara natural berbeda satu dengan yang lainnya baik dalam ketertarikan, kemampuan, serta gaya belajar. Guru dalam SCL ini berperan sebagai fasi- litator yang harus mampu membangkitkan ketertarikan siswa terhadap suatu materi belajar, menentukan sumber materi dan menyediakan wahana, media dan pendekatan cara belajar yang bervariasi pada pembelajaran (Jensen, 2014, p. 77).

Sekolah SMKN 6 Yogyakarta merupakan salah satu sekolah kejuruan yang telah menggunakan kurikulum 2013 sejak kurikulum 2013 dicanangkan. SCL juga digunakan dalam proses pembelajaran di sekolah. Dengan demikian, guru di sekolah SMKN 6 Yogyakarta diharapkan dapat menjadi fasilitator yang harus mampu membangkitkan ketertarikan siswa tehadap materi belajar dan juga dapat menyediakan wahana, media serta pendekatan cara belajar yang bervariasi.

Prodi Kecantikan kulit kelas X merupakan salah satu program studi keahlian kecantikan yang ada di SMKN 6 Yogyakarta. Kurikulum yang diterapkan sudah menggunakan kurikulum 2013, yaitu ada penggabungan beberapa dasar kompetensi keahlian menjadi satu dasar kompetensi kejuruan. Dasar kompetensi kejuruan untuk program kecantikan kulit kelas $X$ adalah mata pelajaran Dasar Kecantikan Kulit, yang terdiri dari Desain Kecantikan, Perawatan Kulit Wajah, Rias Wajah Sehari-hari, dan Perawatan dan Rias Kuku (Kurikulum SMK).

Kompetensi keahlian rias wajah merupakan salah satu dari kompetensi keahlian yang mana materinya dipelajari siswa program kecantikan kulit pada semester 2. Materi ini membahas tentang rias wajah korektif, rias wajah sehari-hari ( rias pagi dan rias malam). Dalam penelitian ini, peneliti membahas rias wajah korektif dikarenakan rias wajah korektif merupakan dasar riasan yang harus dilakukan terlebih dahulu sebelum melakukan bentuk riasan lainnya. Rias wajah dengan tema rias wajah korektif merupakan riasan untuk mengoreksi berbagai bentuk macam wajah dan bagian-bagian wajah. Riasan ini bertujuan untuk membuat bentuk wajah dan bagian-bagian wajah terlihat atau mendekati bentuk yang ideal. 
Namun, dalam pelaksanaan SCL untuk materi rias wajah dengan tema rias wajah korektif belum bisa diterapkan sebagaimana mestinya. Hal ini sesuai dengan hasil wawancara pada salah satu guru kecantikan X pada tanggal 07 Januari 2015, karena materi berkaitan dengan prosedur kerja yang dilakukan pada saat melaksanakan praktik mata pelajaran kompetensi keahlian. Selain itu, guru harus menyetarakan standar langkah-langkah pengerjaan praktik yang prosedural. Hal ini dikarenakan jika diserahkan sepenuhnya kepada siswa untuk mencari materi sendiri akan mengalami perbedaan sehingga menyulitkan siswa pada saat ujian akhir praktik keahlian mereka.

Kendala lain yang dihadapi guru pengampu adalah menyediakan media pembelajaran yang bervariasi. Kendala ini terjadi karena kurangnya kemampuan dan pengetahuan guru dalam membuat berbagai macam media yang dibutukan dalam proses pembelajaran, sehingga guru menggunakan media yang sesuai dengan kemampuan yang dimiliki saja. Guru terkadang hanya menggunakan media tunggal sesuai dengan kemampuannya. Asumsi bahwa "tidak ada media pembelajaran yang baik", memang benar adanya jika kita telaah lebih jauh. Dengan menggunakan media tunggal pastilah banyak keterbatasan yang dialami guru dalam penyampaian materi serta kesulitan dalam membangkitkan ketertarikan siswa terhadap materi pelajaran.

Adapun media yang digunakan yaitu buku cetak dan modul, media lain yang juga digunakan guru yaitu bahanbahan dari internet serta alat bantu berupa model/patung yang digunakan sebagai alat peraga. Guru mengalami kesulitan dalam membangkitkan ketertarikan siswa terhadap materi pelajaran sehingga siswa tidak aktif untuk mencari tahu lebih lanjut materi yang disampaikan dikarenakan media pembelajaran yang kurang bervariasi.

Dalam pembelajaran kompetensi kejuruan Dasar Kecantikan Kulit ini khususnya rias wajah dengan tema rias wajah korektif, guru masih mengalami kesulitan menjelaskan konsep-konsep dasar dari materi yang ada pada pembelajaran rias wajah. Guru masih menggunakan media pembelajaran yang terbatas dan materi disampaikan pada siswa kelas $X$ yang masih belum banyak mengenal dan mengetahui tentang berbagai riasan terutama rias wajah korektif. Adapun keinginan guru untuk menggunakan media pembelajaran yang lebih baik dan menarik, namun guru mengalami kendala dalam pembuatan media dikarenakan kurangnya kemampuan dan pengetahuan guru tentang media pembelajaran lainnya.

Media pembelajaran pada saat ini telah mengalami perkembangan yang cukup pesat terutama di bidang teknologi berbasis komputer. Perkembangan media pembelajaran sekarang tidak hanya dalam penampilannya saja, tetapi juga dalam aplikasinya sudah menggabungkan beberapa media pembelajaran (Bardi \& Jailani, 2015, p. 2). Pengembangan multimedia berbasis komputer dalam pembelajaran yang dapat menggabungkan beberapa media-media yang ada seperi teks, gambar/grafik, audio, video, animasi dan lainnya dikenal dengan sebutan Multimedia. Menurut Neo \& Neo (2009, p 254) teknologi multimedia dalam pendidikan telah menciptakan dampak yang signifikan pada pengembangan konten pembelajaran dan metode berkomunikasi informasi kepada siswa. Multimedia memberi kesempatan untuk melaksanakan pembelajaran aktif yang berpusat pada siswa dimana siswa dapat memilih kata-kata dan gambar yang relevan yang dapat mengubah gaya belajar siswa (Piyayodilokchai et al., 2013, p. 146). Selain itu, studi tentang multimedia yang disampaikan oleh Yang et al. (2013, p. 283) menunjukkan bahwa manusia lebih baik dari gambar dan teks dibangdingkan dari teks saja, karenda dengan gambar dan teks siswa akan lebih kaya mempresentasikan memorinya.

Gayeski (Munir, 2013, p. 2) mendefinisikan multimedia sebagai kumpulan media berbasis komputer dan sistem ko- 
munikasi yang memiliki peran untuk membangun, menyimpan, menghantarkan dan menerima informasi dalam bentuk teks, grafik, audio, video dan sebagainya. Menurut Vernadakis et al. (2010, p. 209) multimedia merupakan alternatif dalam mencapai kebutuhan yang dibutuhkan siswa dalam konteks pembelajaran.

Perkembangan media berupa multimedia pembelajaran ini belum diperkenalkan pada siswa kecantikan kulit kelas X SMKN 6 Yogyakarta. Penggunaan multimedia dapat membantu guru dalam menyampaikan materi dan menghemat waktu, baik waktu menyiapkan pembelajaran maupun dalam proses pembelajaran itu sendiri. Multimedia juga dapat digunakan berulang-ulang sehingga dapat menghemat penggunaan biaya produksi. Selain itu, multimedia dapat membantu siswa untuk belajar mandiri karena multimedia mempunyai kemampuan interaktif dan guru dapat menerapkan pembelajaran yang berpusat pada siswa (SCL) yang merupakan gambaran pelaksanaan kurikulum 2013.

\section{Metode Penelitian}

Penelitian ini menggunakan jenis penelitian research and development (RED), yaitu penelitian yang bertujuan untuk menghasilkan produk yang dapat digunakan untuk memperbaiki dan meningkatkan kualitas pendidikan, mencakup berbagai aspek pendidikan. Dalam penelitian ini, peneliti menghasilkan produk media pembelajaran yang berupa multimedia pembelajaran rias wajah dalam meningkatkan pengetahuan siswa kecantikan kulit kelas $X$.

Model pengembangan dalam produk ini diadaptasi dari Alessi \& Trollip (2001, pp. 410-413). Tahapan yang ada dalam model yang dikembangkan sesuai mengikuti prosedur Alessi dan Trollip adalah tahap perencanaan (planning), desain (design) dan pengembangan (development). Tahap Perencanaan (planning), yang dilakukan dalam tahap ini sebagai berikut.
Pertama adalah mendefinisikan ruang lingkup kajian (define the scope). Materi yang akan ditampilkan dirujuk dari kurikulum, silabus, dan rencana pelaksanaan pembelajaran (RPP) SMKN 6 Yogyakarta. Pengkajian silabus dan RPP yang digunakan dalam penelitian pengembangan multimedia ini bekerja sama dengan guru kecantikan kulit SMKN 6 Yogyakarta dengan kompetensi dasar Rias Wajah dengan tema Rias Wajah Korektif.

Kedua adalah mengidentifikasi karakteristik siswa (identify learner characteristic). Identifikasi karakteristik siswa bertujuan untuk mengetahui kemampuan yang dimiliki siswa untuk dapat mengikuti pembelajaran dengan multimedia. Identifikasi dilakukan dengan menggunakan lembar analisis kebutuhan ketika melakukan prasurvei di sekolah SMKN 6 Yogyakarta. Ketiga, menentukan dan mengumpulkan sumber-sumber (determine and collect resources) dari buku, artikel, dan internet tentang materi Rias Wajah khusus Rias Wajah Korektif sebelum tahap desain multimedia pembelajaran sebagai referensi dalam menyusun materi pada multimedia pembelajaran rias wajah. Keempat, melakukan brainstroming (conduct initial brainstroming) yaitu melakukan diskusi dengan guru mata pelajaran Dasar Kecantikan Kulit dan teman sejawat dalam rangka membuat konsep desain multimedia yang akan dikembangkan.

Tahap desain (design) terdiri dari: (a) mengembangkan ide kontens pembelajaran (develop initial content ideas) berdasarkan silabus dan RPP pembelajaran rias wajah di SMK Negeri 6 Yogyakarta; (b) melakukan analisis konsep dan tugas (conduct task and concept analysis) yang berkaitan dengan materi yang akan disampaikan pada multimedia yang akan dikembangkan dan mengumpulkan bahan berupa teks, gambar, animasi dari berbagai sumber; (c) mendeskripsikan program pendahuluan (do a preliminary program description) yang berisi tentang penjelasan produk mulai dari judul, materi, dasar pengembangan produk, pengembangan dan infor- 
masi lainnya terkait dengan produk; (d) membuat flowcharts dan storyboard (create flowchart and storyboard). Flowcharts yaitu diagram alur yang digunakan sebagai alur navigasi dari media yang dikembangkan. Storyboard, bertujuan untuk membuat frame-frame yang tepat dan menarik.

Tahap pengembangan (development) terdiri dari: (a) mengembangkan multimedia dengan menggunakan program Macromedia Flash; (b) melakukan evaluasi formatif dengan alpha testing, yaitu menvalidasi produk yang dilakukan oleh ahli media dan ahli materi. (c) membuat revisi yang pertama terhadap produk yang telah dibuat berdasarkan hasil evaluasi formatif dengan alpha testing; (d) melakukan evaluasi formatif dengan beta testing, yaitu menguji produk ke enam orang siswa untuk mengetahui tanggapan siswa terhadap produk yang dikembangkan. Siswa yang dipilih diharapkan mewakili tingkat kecerdasan siswa, yaitu siswa dengan tingkat kecerdasan tinggi, kecerdasan rata-rata dan kecerdasan rendah; (e) melakukan revisi akhir produk multimedia pembelajaran berdasarkan hasil evaluasi formatif dengan beta testing; (f) menghasilkan multimedia pembelajaran rias wajah yang telah dapat digunakan untuk melakukan evaluasi selanjutnya di lapangan atau pada siswa yang mempelajari rias wajah; (g) melakukan evaluasi sumatif terhadap multimedia yang dikembangkan dengan menggunakan pre-test dan post-test untuk mengetahui efektivitasnya dalam proses pembelajaran dan melakukan uji lapangan untuk mengetahui dan mengidentifikasi kekurangan program multimedia.

Uji coba pada penelitian ini terdiri dari tiga tahap. Pertama adalah uji alpha/validasi ahli yang mana hasil validasi akan dijadikan bahan untuk merevisi produk awal. Kedua adalah uji beta dilakukan untuk menguji apakah kualitas multimedia yang dihasilkan telah layak. Tindakan yang dilakukan adalah dengan meminta penilaian dari enam orang siswa yang dipilih berdasarkan kemampuan akademik dengan rekomendasi dari guru mata- pelajaran yaitu tinggi, sedang, dan kurang. Berdasarkan masukan tersebut dilakukan revisi terakhir terhadap produk, maka diperoleh produk yang siap digunakan pada uji coba produk.

Subjek uji coba adalah siswa kecantikan kelas X SMKN 6 Yogyakarta tahun ajaran 2014/2015 yang berjumlah 40 orang. Uji coba produk dilaksanakan pada bulan Juni 2015.

Jenis data dalam penelitian ini adalah data kualitatif dan data kuantitatif. Data kualitatif diperoleh dari komentar dan saran para ahli, sedangkan data kuantitatif diperoleh dari hasil validasi oleh ahli materi, ahli media, dan siswa. Data kuantitatif berupa skor, selanjutnya dianalisis dan dikonversikan ke dalam bentuk data kualitatif. Hasil konversi tersebut kemudian menjadi tolak ukur untuk menentukan kelayakan pengembangan bahan ajar berbasis web. Data penilaian hasil belajar diperoleh dari hasil pretest dan posttest berupa data kuantitatif. Sedangkan penilaian respon siswa diperoleh dari data kuantitatif yang dikonversikan menjadi kualitatif. Instrumen atau alat pengumpulan data yang digunakan berupa observasi, wawancara, lembar angket (untuk validasi ahli materi dan ahli media serta lembar angket untuk penilaian atau tanggapan uji coba produk).

Data hasil penelitian ini adalah berupa tanggapan ahli materi, ahli media dan siswa terhadap kualitas produk yang telah dikembangkan ditinjau dari aspek materi dan aspek media. Data berupa komentar, saran, revisi, dan hasil pengamatan peneliti selama proses uji coba dianalisis secara deskriptif kualitatif, dan disimpulkan sebagai masukan untuk memperbaiki atau merevisi produk yang telah dikembangkan.

Sementara, data berupa skor tanggapan ahli materi, ahli media dan siswa yang diperoleh melalui kuesioner, dianalisis secara deskriptif kuantitatif dengan teknik kategorisasi. Langkah-langkah yang digunakan untuk menentukan kriteria kualitas produk yang telah dikembangkan, 
sebagai berikut: (a) Data yang diperoleh dari kuesioner tentang tanggapan siswa diubah dulu menjadi data interval sebagai berikut: Sangat Baik $=5$, Baik $=4$, Cukup $=$ 3 , Kurang $=2$, Sangat Kurang $=1$.

Seandainya siswa memberi tanggapan "sangat baik" pada suatu butir pertanyaan/pernyataan, maka skor butir pertanyaan tersebut sebesar " 5 ", demikian seterusnya. Skor yang diperoleh, kemudian dikonversikan menjadi kualitatif skala lima, dengan acuan rumus yang dikutip dari yang dikembangkan Sukarjo (2006, p. 53) dapat dilihat pada Tabel 1.

Tabel 1. Kriteria Penilaian

\begin{tabular}{l}
$\overline{\text { Rumus }}$ \\
\hline$X>\overline{X i}+1,8 \mathrm{Sb}_{\mathrm{i}}$ \\
$\overline{X i}+0,6 \mathrm{Sb}_{\mathrm{i}}<X \leq \overline{X i}+1,8 \mathrm{Sb}_{\mathrm{i}}$ \\
$\overline{X i}-0,6 \mathrm{Sb}_{\mathrm{i}}<X \leq \overline{X i}+0,6 \mathrm{Sb}_{\mathrm{i}}$ \\
$\overline{X i}-1,8 \mathrm{Sb}_{\mathrm{i}}<X \leq \overline{X i}-0,6 \mathrm{Sb}_{\mathrm{i}}$ \\
$X \leq \overline{X i}-1,8 \mathrm{Sb}_{\mathrm{i}}$ \\
\hline
\end{tabular}

Keterangan:

$$
\begin{aligned}
\mathrm{X}_{i}= & \text { Rerata skor ideal }=1 / 2 \text { (skor maksimal } \\
& \text { ideal }+ \text { skor minimal ideal) } \\
\mathrm{SB}_{i}= & \text { Simpangan baku ideal }=1 / 6 \text { (skor } \\
& \text { maksimal ideal }- \text { skor minimal ideal) } \\
\mathrm{X} \quad= & \text { Skor aktual }
\end{aligned}
$$

Tabel 2. Konversi Rerata Skor menjadi Kriteria untuk Menilai Kelayakan Produk

\begin{tabular}{ccc}
\hline Nilai & Kriteria & $\begin{array}{c}\text { Interval Rerata } \\
\text { Skor }\end{array}$ \\
\hline 5 & Sangat Baik & $4,2<\mathrm{x}$ \\
4 & Baik & $3,4<\mathrm{x}<4,2$ \\
3 & Cukup & $2,6<\mathrm{x} \leq 3,4$ \\
2 & Kurang & $1,8<\mathrm{x} \leq 2,6$ \\
1 & Sangat Kurang & $\mathrm{x} \leq 1,8$ \\
\hline
\end{tabular}

Berdasarkan hasil konversi skor ke nilai maka akan diperoleh nilai produk yang sedang dikembangkan. Untuk mengetahui bahan ajar efektif meningkatkan kemampuan kognitif siswa dengan melihat perubahan kemampuan awal siswa dengan membandingkan nilai pretest dan posttest siswa sebelum dan sesudah menggunakan multimedia pembelajaran rias wajah. Peneliti juga melihat persentase ketuntasan belajar siswa berdasarkan kriteria ketuntasan minimal di SMKN 6 Yogyakarta yang membatasi KKM untuk mata pelajaran rias wajah minimal " 75 ".

Pada penelitian ini uji tes sumatif dilakukan hanya dengan satu kelas eksperimen tanpa menggunakan kelas kontrol, sehingga untuk menghitung besarnya effect size pada penelitian ini hanya melibat $\mathrm{d}$ (gain).

\section{Hasil Penelitian dan Pembahasan}

Pada tahap perencanaan kegiatan yang dilakukan sebagai berikut: (a) mendefenisikan ruang lingkup penelitian, yaitu menetapkan kompetensi inti dan kompetensi dasar. Pertama, menghayati dan mengamalkan ajaran agama yang dianutnya. Kedua, menghayati dan mengamalkan perilaku jujur, disiplin, tanggungjawab, peduli (gotong royong, kerjasama, toleran, damai), santun, responsif dan pro-aktif dan me-nunjukkan sikap sebagai bagian dari solusi atas berbagai permasalahan dalam ber-interaksi secara efektif dengan lingkungan sosial dan alam serta dalam menempatkan diri sebagai cerminan bangsa dalam pergaulan dunia. Ketiga, memahami dan menerapkan pengetahuan faktual, konseptual, prosedural dalam ilmu pengetahuan, teknologi, seni, budaya, dan humaniora dengan wawasan kemanusiaan, kebangsaan, kenegaraan, dan peradaban terkait fenomena dan kejadian, serta menerapkan pengetahuan prosedural pada bidang kajian yang spesifik sesuai dengan bakat dan minatnya untuk memecahkan masalah. Kempat adalah mengolah, menalar, dan menyaji dalam ranah konkret dan ranah abstrak terkait dengan pengembangan dari yang dipelajarinya di sekolah secara mandiri, dan mampu menggunakan metoda sesuai kaidah keilmuan. Kompetensi dasar yang dikembangkan dalam 
mata pelajaran rias wajah ini adalah menguraikan rias wajah dengan indikator yakni menjelaskan rias wajah korektif dan melakukan rias wajah. (b) mengidentifikasi karakteristik siswa, karakteristik siswa jurusan kecantikan kulit kelas X SMKN 6 Yogyakarta yang sudah mampu menggunakan komputer, dan juga tertarik untuk belajar melalui komputer. (c) menentukan dan mengumpulkan sumber belajar yang digunakan, sumber-sumber atau referensi yang dijadikan acuan dalam proses pengembangan multimedia. Referensi yang dapat dijadikan acuan untuk pengembangan konten paket bahan ajar, baik dalam bentuk teks, gambar, dan animasi yang diperoleh dari buku dan internet. (d) melakukan brainstorming, melakukan diskusi dengan dosen/guru kecantikan dan temanteman sejawat, mengenai konten yang akan dikembangkan.

Pada tahap desain, peneliti melakukan analisis konsep dan tugas yang berkaitan dengan topik, pembuatan flowchart, pembuatan storyboard multimedia pembelajaran, pengumpulan sumber-sumber untuk mengisi konten, dan menentukan software yang digunakan; (a) melakukan analisis konsep dan tugas, yaitu dengan menentukan indikator yang ingin dicapai dan pembuatan silabus serta RPP; (b) pembuatan flowchart, bertujuan untuk menggambarkan alur untuk proses penggunaan multimedia (c) menggabungkan bagianbagian (teks, gambar, animasi, dan musik) ke dalam program macromedia flash yang mengacu pada flowchart dan storyboard.

Produk yang dihasilkan dalam penelitian ini multimedia pembelajaran yang berisi bahan penarik perhatian, petunjuk, kompetensi dasar, materi, latihan, dan soal. Produk yang dikembangkan ini telah melalui rangkaian persiapan dan penggabungan materi yang akan dijadikan konten, serta materi pendukung yang lain seperti contoh soal dan pembahasan, sehingga nantinya produk ini dapat untuk dievaluasi tingkat evaluasi formatif dan sumatif.

\section{Hasil Uji Coba Produk}

Data diperoleh dari tiga kegiatan uji coba yang dilakukan, yaitu dari data uji Alpha, data uji coba beta, dan data hasil uji coba produk. Data uji coba ahli/validasi ahli dilakukan untuk menilai atau menentukan kevalidan multimedia pembelajaran rias wajah yang dihasilkan, serta meminta masukan atau komentar dari beberapa ahli. Data yang diperoleh berupa data kuantitatif, yaitu skor penilaian ahli dan data kualitatif berupa saran atau masukan yang akan digunakan untuk memperbaiki produk. Data uji alpha terdiri dari: (1) terdapat dua orang ahli multimedia sebagai ahli media. Penilaian dari ahli media terhadap keseluruhan instrumen diperoleh skor sebesar 4,2 dalam kategori baik, oleh karena itu dari sisi media dinyatakan "layak" diujikan pada tes berikutnya yaitu ujibeta; (2) terdapat dua orang ahli di bidang kecantikan sebagai ahli materi. Dengan berpedoman hasil konversi dapat disimpulkan bahwa penilaian dari kedua ahli materi terhadap keseluruhan instrumen diperoleh rerata penilaian sebesar 4,9 dalam kategori sangat baik, oleh karena itu dari sisi materi dinyatakan "layak" diujikan pada tes berikutnya yaitu uji beta.

Kemudian data uji coba beta dilakukan dengan melibatkan enam orang siswa yang dipilih berdasarkan kemampuan akademik berdasarkan rekomendasi guru kecantikan kulit yaitu tinggi, sedang, dan rendah untuk mencoba dan mengamati produk yang dihasilkan. Skor penilaian berdasarkan data uji beta yang melibatkan enam orang siswa adalah 4,4 dalam kategori sangat baik.

Selanjutnya uji coba produk melibatkan 40 siswa kecantikan kulit kelas $X$ SMKN 6 Yogyakarta. Siswa diminta sebelumnya membuka multimedia melalui komputer dengan cara membuka menumenu yang tersedia, melihat dan mempelajari materi rias wajah korektif yang telah tersedia dalam multimedia dan mengerjakan latihan serta soal yang telah 
disediakan setelah mempelajari materi rias wajah korektif. Kemudian siswa diminta tanggapannya dengan cara mengisi kuesioner yang telah diberikan. Jumlah skor penilaian berdasarkan data uji coba multimedia adalah 4,5 dalam kategori sangat baik.

Pada uji coba program dilakukan juga pretest dan posttest dengan soal pilihan ganda untuk mengetahui kemampuan atau hasil belajar dari materi rias wajah korektif dengan menggunakan multimedia pembelajaran rias wajah.

\section{Analisis Data}

Validasi ahli media dilakukan oleh dua orang dosen ahli media yang meliputi aspek tampilan dan aspek pemograman. Hasil validasi menunjukkan bahwa kelayakan multimedia pembelajaran rias wajah adalah "Baik", sehingga dapat dilanjutkan ke tahap uji beta dengan terlebih dahulu melakukan revisi awal sesuai yang disarankan.

Untuk memberikan gambaran tentang kualitas dari produk berdasarkan penilaian dari kedua ahli media dapat dilihat pada Gambar 1.

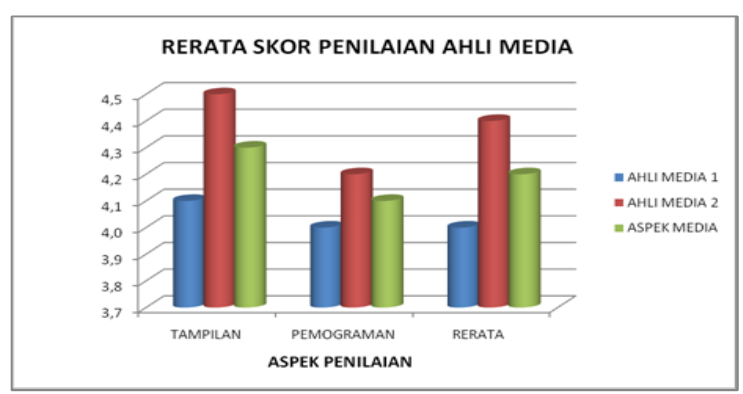

Gambar 1. Grafik Penilaian Kualitas menurut Ahli MediaValidasi

Ahli materi dilakukan oleh dua orang dosen ahli materi yang meliputi aspek pembelajaran dan isi. Hasil validasi menunjukkan bahwa kelayakan materi rias wajah korektif adalah "Sangat Baik", sehingga dapat dilanjutkan ke tahap uji beta dengan terlebih dahulu melakukan revisi awal sesuai yang disarankan.

Untuk memberikan gambaran tentang kualitas dari materi rias wajah ko- rektif berdasarkan penilaian dari kedua ahli materi dapat dilihat pada Gambar 2.

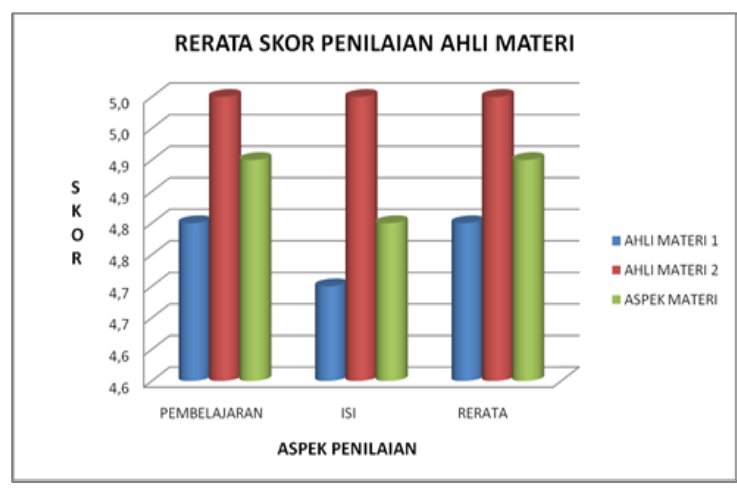

Gambar 2. Grafik Penilaian Kualitas menurut Ahli Materi

Analisis dilakukan berdasarkan data yang diperoleh pada uji coba beta pada siswa. Uji beta dilakukan pada siswa sebanyak enam orang, yaitu dua orang yang berkemampuan tinggi, dua orang berkemampuan sedang dan dua orang berkemampuan rendah. Pemilihan siswa dilakukan langsung oleh guru mata pelajaran. Rerata penilaian dan termasuk kategori "Sangat Baik".

Untuk memberikan gambaran tentang kualitas dari multimedia pembelajaran rias wajah berdasarkan penilaian dari siswa dapat dilihat pada Gambar 3.

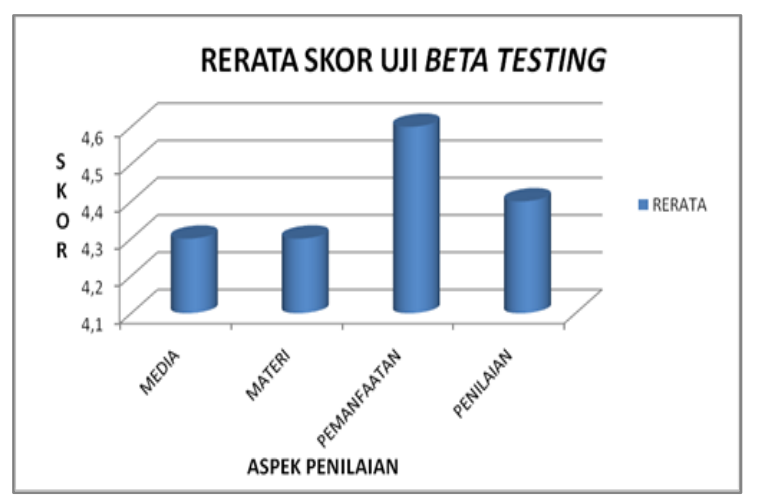

Gambar 3. Grafik Penilaian Kualitas menurut Siswa

Analisis Keefektivan Pembelajaran

Setelah dilakukan evaluasi formatif, maka tahap selanjutnya melakukan evaluasi sumatif dengan uji coba yang melibatkan 40 orang siswa dalam proses pembelajaran sebenarnya. Uji coba ini dimak- 
sudkan untuk mengidentifikasi dan mengetahui kekurangan dari multimedia pembelajaran rias wajah dan mengetahui efektivitas dalam pembelajaran. Hasil respon siswa selama menggunakan media dapat diketahui bahwa kualitas multimedia yang dikembangkan termasuk kriteria "Sangat Baik" dengan rerata 4,5. Untuk memberikan gambaran yang lebih jelas tentang respon siswa dalam menggunakan multimedia pembelajaran rias wajah dapat dilihat pada Gambar 4.

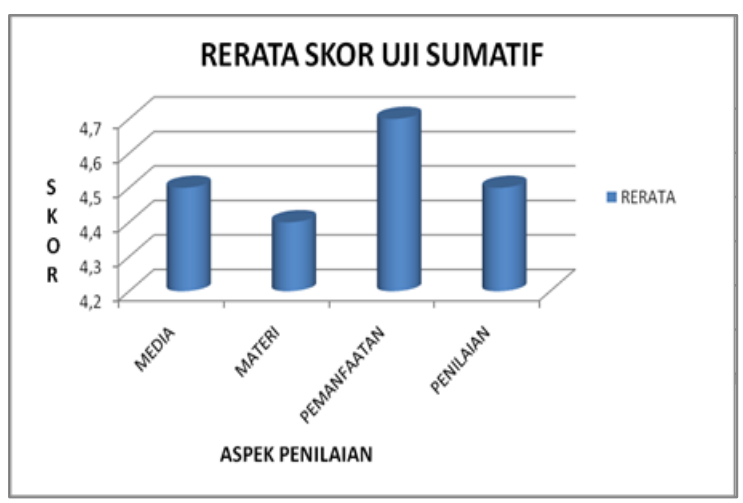

Gambar 4. Grafik Respon Siswa

Selain data terkait respon siswa, selanjutnya untuk melihat efektifitas penggunaan multimedia padamateri rias wajah dalam proses pembelajaran, maka dilakukan tes sumatif dengan memberikan pretest dan posttest pada siswa. Proses yang dilakukan untuk mengukur pencapaian kompetensi siswa secara berkelanjutan dalam proses pembelajaran dan menentukan keberhasilan belajar siswa. Analisis efektivitas hasil belajar pada soal pilihan ganda. Siswa yang mengikuti uji kompetensi dengan perolehan rerata pretest 61,0 dan rerata posttest 83,9 . Pretest dilakukan sebagai penjajakan penguasaan materi, sedangkan posttest dilakukan untuk mengetahui peningkatan pengetahuan siswa setelah menggunakan multimedia. Nilai peningkatan pengetahuan siswa dari soal pilihan ganda dapat dilihat pada Gambar 5.

Pencapaian kompetensi seorang siswa dapat dilihat dari keberhasilan siswa tersebut mencapai nilai KKM (Kriteria Ketuntasan Minimal). Siswa dikatakan tuntas jika mencapai nilai $\geq 7,5$. Sehingga ber- dasarkan nilai yang didapat bahwa persentase ketuntasan belajar siswa pada pretest $18,9 \%$ dan posttest $100 \%$.

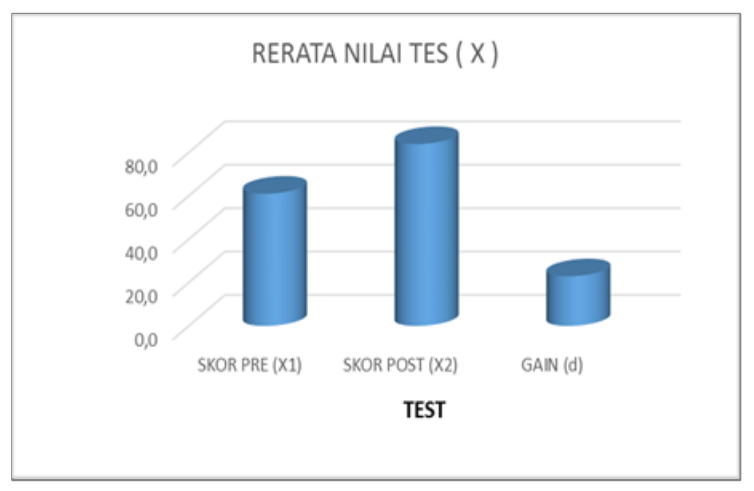

Gambar 5. Grafik Rerata Nilai Hasil Pretest dan Postest

Dengan demikian ditinjau dari segi efektivitasnya baik dari respon siswa dan nilai hasil belajar maka pengembangan multimedia pembelajaran rias wajah dihasilkan telah efektif.

\section{Kajian Produk Akhir}

Setelah melalui beberapa tahapan validasi baik validasi dari ahli media dan ahli materi, maupun beta testing dan tanggapan siswa, produk pembelajaran rias wajah hasil pengembangan tersebut sudah layak menjadi produk akhir yang dapat disebarluaskan dan diimplementasikan kepada para pengguna. Kelayakan tersebut dapat dilihat dari skor penilaian ahli media dengan kategori baik, skor peniaian dari ahli materi dengan kategori sangat baik, dan skor penilaian dari beta testing dengan kategori sangat baik.

Sesuai dengan kriteria kualitas produk yang telah ditetapkan pada bab III bahwa produk yang dikembangkan dianggap layak jika aspek-aspek yang dinilai pada produk pembelajaran memperoleh nilai minimal 4 atau baik. Dengan demikian, multimedia pembelajaran rias wajah dalam meningkatkan pengetahuan siswa SMK kecantikan kulit kelas $\mathrm{X}$ yang dikembangkan layak digunakan sebagai sumber belajar karena nilai yang didapat dalam kategori baik dan sangat baik. 


\section{Simpulan dan Saran}

Simpulan

Berdasarkan hasil penelitian dan pengembangan, dapat disimpulkan bahwa produk multimedia pembelajaran rias wajah dalam meningkatkan pengetahuan siswa SMK kecantikan kulit kelas $\mathrm{X}$ adalah sebagai beriktu. Pertama, multimedia pembelajaran yang dikem-bangkan dinilai layak digunakan sebagai sumber belajar ditinjau dari media, materi, dan penilaian siswa. Kelayakan tersebut dapat dilihat dari skor penilaian ahli media 4,2 dengan kategori baik, skor ahli materi 4,9 dengan kategori sangat baik, dan skor penilaian siswa 4,4 dengan kategori sangat baik.

Kedua, multimedia pembelajaran Rias Wajah yang menggunakan Macromedia Flash dinilai efektif karena dapat meningkatkan pengetahuan siswa dalam rias wajah korektif. Hal ini dibuktikan dengan hasil nilai pretest dengan rata-rata nilai 61,0 dan nilai posttest dengan rata-rata nilai 83,9. Rata-rata nilai posttest lebih baik dibandingkan dengan rata-rata nilai pretest.

Saran

Berdasarkan hasil penelitian yang sudah disajikan dapat disarankan sebagai berikut. Pertama, multimedia pembelajaran rias wajah dalam meningkatkan pengetahuan siswa kecantikan kulit kelas $X$ sesuai dengan desain pembelajaran, sesuai dengan silabus dan RPP serta sudah melalui validasi oleh para ahli media, ahli materi, dan tanggapan siswa, maka pemanfaatan multimedia ini dapat diimplementasikan guru pada proses pembelajaran rias wajah dengan tema rias wajah korektif. Kedua, guru diharapkan mampu menggunakan multimedia pembelajaran rias wajah sebagai media dalam proses pembelajaran yang efektif untuk meningkatkan pemahaman siswa tentang materi yang diajarkan, sehingga guru dapat menggunakan multimedia secara klasikal dalam pembelajaran dan digunakan secara terus menerus.

\section{Daftar Pustaka}

Alessi, S. M., \& Trollip, S. R. (2001). Multimedia for learning methods and development. Massachusetts: Allyn \& Bacon.

Bardi, B., \& Jailani, J. (2015). Pengembangan multimedia berbasis komputer untuk pembelajaran matematika bagi siswa SMA. Jurnal Inovasi Teknologi Pendidikan, 2(1), 49-63. Retrieved from http://journal.uny.ac.id/index.php /jitp/article/view/5203

Dananjaya, U. (2013). Media pembelajaran aktif. Bandung: Nuansa Cendekia.

Jensen, Ben. (2012). Focus PD on Student. Journal The Phi Delta Kappan, 94(1): 41-44.

Munir. 2013. Multimedia: konsep $\mathcal{E}$ aplikasi dalam pendidikan. Bandung: Alfabeta.

Nanney, Barbara. (2004). Student-centered learning. Diakses 22 Juli 2015 dari http://www2.gsu.edu/ mstswh/c ourses/it7000/papers/studenthtm.

Neo, Mai, \& Neo, Tse-kian. (2009). “Engaging students in multimediamediated constructivist learning students' perceptions." Journal Educational Technology \& Society 12(2): 254-66.

Piyayodilokchai, Hongsiri et al. (2013). "A 5e learning cycle approach - based, multimedia-supplemented instructional unit for structured query language." Journal Educational Technology \& Society 16(4): 146-59.

Presiden RI. (2013). Permendikbud nomor 81a tahun 2013 tentang implementasi kurikulum garuda.

Republik Indonesia. (2003). Undang-undang RI nomor 20 tahun 2003, tentang sistem pendidikan nasional. 
Sukarjo. (2006). Kumpulan materi evaluasi pembelajaran. Yogyakarta: UNY.

Vernadakis, Nikolaos et al. (2010). Athens 2004 team leaders ' attitudes toward the educational multimedia application 'leonidas.' Journal Educational Technology \& Society 13(1): 208-19.
Yang, Che-ching, Shian-shyong Tseng, Anthony Y H Liao, and Tyne Liang. (2013). "Situated poetry learning using multimedia resource sharing approach." Journal Educational Technology E Society 16(2): 282-95. 